\title{
Література:
}

1. Декларація про принципи міжнародного права, що стосуються дружніх відносин та співробітництва між державами відповідно до Статуту Організації Об'єднаних Націй від 24.10.1970 року. URL: Режим доступу: http://zakon.rada.gov.ua/laws/show/995_569.

2. Мазаракі А., Воронова С. Стратегічні напрямки економічної інтеграції України в Європейський Союз. Вісник Тернопільської академії народного господарства. 2000. Спец. випуск № 15-3.

3. Актуальні питання методології та практики науково-технологічної політики: монографія [за ред. Б. А. Малицького].К.: УкрIНTЕI, 2001. 204 с.

4. Дежина И. Г. Влияет ли глобализация на научную политику в России. Форсайт. 2008. №4(8). с. 42-49.

5. Петренко Н.С. Програмне забезпечення інноваційного розвитку України в умовах євроінтеграції [дис. робота, спец. 08.00.03]. Чернігів. 2018.

5. European research area. Official website of European Commission. URL: http://ec.europa.eu/research/era/index_en.htm (Last accessed: 28.10.2017).

6. BILAT-UKR*AINA : project successfully completed. URL: http://www.bilat-ukr.eu/(Last accessed: 28.10.2017).

7.Community research and development information service. URL: http://cordis.europa.eu/home_en.html (Last accessed: 28.10.2017).

8. Horizon 2020 The EU Framework Programme for Research and Innovation. URL: http://ec.europa.eu/research/horizon2020/index_en.cfm?pg=h2020 (Last accessed: 28.10.2017).

9. European union funding for research and innovation. URL: http://2020.pntu.edu.ua/ (Last accessed: 29.10.2017)

10. NIP/Ukraine. URL: www.fp7-ncp.kiev.ua (Last accessed: 29.10.2017).

УДК $338.1+334.7$

JEL classification: O14, O33, O44

Скоробогатова Н.С. канд. економ. наук, дочент ORCID ID: 0000-0002-2741-7629

Національний технічний університет України «Київський політехнічний інститут імені Ігоря Сікорського»

\section{КОНЦЕПТУАЛЬНІ ЗАСАДИ ФОРМУВАННЯ СТАЛОГО РОЗВИТКУ СУСПІЛЬСТВА В КОНТЕКСТІ ІНДУСТРІЇ 4.0}

\section{CONCEPTUAL BASIS FOR FORMATION OF SUSTAINABLE DEVELOPMENT OF SOCIETY IN THE CONTEXT OF INDUSTRY 4.0}

У статті досліджуються кониептуальні засади формування сталого розвитку суспільства з врахуванням перетворень промислової револючії Індустрія 4.0. В основу концеепиії сталого розвитку покладено організацію суспільного виробництва для задоволення сучасних потреб людства, не зашкодивщи інтересам майбутніх поколінь. Встановлено, щуо існують різні методологічні підходи до оцінювання рівня сталого розвитку країн світу. На основі аналізу Індексу досягнення сталого розвитку (SDG) доведено, щэо жодна з краӥн світу не досягла 100\% виконання цілей сталого розвитку. 
Більшою мірою наближені до досягнення изілей сталого розвитку скандинавські країни та краӥни північної Свропи. Встановлено, щуо група високорозвинених краӥн иієї ж частину світу $є$ лідерами за Індексом екологічної ефективності (ЕРI). Аналіз результатів оцінювання рівня сталого розвитку за методологію Світового иентру даних з геоінформатики та сталого розвитку на основі компонентів якості та безпеки життя також виявив серед лідерів зазначені країни. Доведено, щуо високорозвинені країні, спрямовуючи частину витрат на виконання сочіальних та екологічних вимог, роблять спробу забезпечити сталий розвиток суспільства. Кореляційний аналіз між складовими доданої вартості ВBП, EPI, GINI, високотехнологічним експортом та витратами на дослідження дозволив виявити наступні закономірності. Країни, які мають високий рівень доходів на душу населення, мають різну структуру доданої вартості ВВП, проте всі вони є інноваційно активними. Виявлено щеільний взаємозв'язок між розвитком IT-технологій та EPI, щуо свідчить про зменшення шкідливого впливу на навколишнє середовище країн, які мають наукоємне виробництво та спеціалізуються на нематеріальному виробництві. Доведено неоднозначний вплив технологій Індустрії 4.0 на суспільство: позитивний вплив на навколишне середовище при одночасній ймовірності виникнення сочіальних конфліктів через перехід до повної автоматизачї виробництва та заміщення людини технікою. Систематизовано заходи, необхідні для забезпечення сталого розвитку України, на засадах реалізаиії Індустрії 4.0 (індустріалізація розвитку промислових високотехнологічних сегментів економіки, створення інноваційної промислової екосистеми, прискорення кластеризації та дигіталізації з врахуванням сутності процесів Індустрї 4.0 та ін.).

Ключові слова: сталий розвиток, промислова революція 4.0, глобальна конкурентоспроможність, ІТ-технології, стратегія розвитку, індекс екологічної ефективності, якість та безпека життя.

The article is devoted to the conceptual foundations for the formation of a sustainable development of society, taking into account the transformations of the industrial revolution Industry 4.0.The organization of social production to meet the modern needs of people, which does not harm the interests of future generations was proposed to the basis of the concept of sustainable development. It was established that there are various methodological approaches to assessing the level of sustainable development of the countries. Based on the analysis of the Sustainable Development Index (SDG), it has been proven that no country in the world has achieved $100 \%$ of the goals of sustainable development. Scandinavian countries and countries of northern Europe more achieved the goal of sustainable development. It was established that the group of highly developed countries of this part of the world are leaders in the Environmental Performance Index (EPI).The results of the assessment of the level of sustainable development in accordance with the methodology of the World Data Centre for Geoinformatics and Sustainable Development were analysed. The quality and safety components of life were put at the basis of the assessment. Among the leaders were the same countries. It was proved that highly developed countries directed the part of the costs of meeting social and environmental requirements. In this way, they try to ensure the sustainable development of society. The correlation analysis between components of added value of GDP, EPI, GINI, high-tech exports and research expenditures was carried out. The analysis allowed to reveal the following regularities. Countries that have a high income per capita have a different structure of added value of GDP, but they are all innovative. The strong correlation between the development of IT-technologies and EPI was found. This showed a decrease in the harmful effects on the environment of those countries that have a science-intensive production and specialize in non-material production. The two-sided influence of technologies Industry 4.0 on society was proved: positive environmental impact and high probability of occurrence of social conflicts due to the full automation of production and the replacement human by technology. The measures that were necessary to ensure sustainable 
development of Ukraine on the basis of the implementation of Industry 4.Owere systematized (industrialization of the development of industrial high-tech segments of the economy, creation of an innovative industrial ecosystem, cauterization and digitalization taking into account the essence of the processes of the Industry 4.0 etc.).

Keywords: sustainable development, Industry 4.0, global competitiveness, ITtechnology, development strategy, the Environmental Performance Index, quality of life and security of life.

Вступ. Перетворення у промисловості, що відбуваються під впливом інноваційних проваджень, дозволяють збільшити обсяги та підвищити якість вироблюваної продукції, підвищити ефективність виробництва. Отримані додаткові прибутки дозволяють здійснювати інвестиції у подальший розвиток підприємства, водночас збільшуючи його вартість для власників. Безперечні переваги отримують як виробники продукції (послуг), так i споживачі, отримуючи більш якісну, функціональну продукцію у скорочений термін, при можливому одночасному зниженні витрат. Тому вважаємо, що підвищення рівня інноваційного розвитку країни в рамках промислової революції Індустрія 4.0 дозволяє забезпечити ії сталий розвиток.

Проблематикою сталого розвитку займалося багато вітчизняних та закордонних науковців. Розробці концепції сталого розвитку та методології оцінювання його рівня присвячено роботи А. О. Болдака[3], О. Б. Ватченка [5], Н. В. Васюткіної [4], С. В. Войтка [3], О. А. Гавриша [3], 3. В. Герасимчука [6], Б. М. Данилишина [7], Г. Дейлі [8], I. М. Джигирей [3], М. 3. Згуровського [1, 2, 3, 19], В.М. Ільченка [5], Л. Г.Мельника [8], С. Л. Пакуліна [10] та інших [16], [15], [17, 20]. В Україні дослідження питань сталого розвитку країн світу також здійснюється Світовим центром даних з геоінформатики та сталого розвитку [23]. Водночас, слід відзначити, що поза увагою залишаються питання врахування особливостей суспільного розвитку з врахуванням сучасних напрямів реалізації Індустрії 4.0.

Постановка завдання. Метою дослідження $є$ аналіз факторів впливу на сталий розвиток суспільства та визначення шляхів забезпечення збалансованого розвитку 3 врахуванням реалізації четвертої промислової революції Індустрія 4.0. Для досягнення поставленої мети було визначено такі завдання: дослідити методичні підходи до оцінювання рівня сталого розвитку країн світу; проаналізувати вплив матеріальних та нематеріальних чинників на збалансований розвиток економіки країни; здійснити критичних аналіз впливу перетворень Індустрії 4.0 на економічний, соціальний та екологічний розвиток країни; визначити заходи, необхідні для реалізації та макро- та мікрорівнях задля забезпечення сталого розвитку суспільства в умовах Індустрії 4.0 (на прикладі України).

Методологія. Теоретико-методологічну основу дослідження становлять наукові праці провідних вітчизняних та зарубіжних науковців в області сталого розвитку, методологічні положення провідних агенцій світу щодо оцінювання рівня сталого розвитку суспільства та його складових. Вирішення наукових завдань здійснювалось 3 використанням наступних методів дослідження: аналізу та синтезу(для порівняння методичних підходів 
до оцінювання рівня сталого розвитку країн світу); порівняння та узагальнення (для обгрунтування особливостей розвитку країн на впливу та впливу на нього фінансових та нефінансових факторів); метод кореляційного аналізу (для виявлення та аналізу взаємозв'язків між показниками сталого розвитку та їх складовими); метод критичного аналізу (для оцінки впливу Індустрії 4.0 на економічний, екологічний та соціальний розвиток суспільства); системний та комплексний підходи (для визначення заходів щодо забезпечення сталого розвитку України в умовах Індустрії 4.0).

Результати дослідження. Суть концепції сталого розвитку полягає задоволенні сучасних потреб людства при одночасному захисті інтересів майбутніх поколінь [1, 19]. Сталий розвиток суспільства визначається збалансованістю його розвитку в економічному, соціальному та екологічному аспектах. Розробкою методології оцінювання та формування стратегії сталого розвитку на національному та міжнародному рівні займаються багато урядових та неурядових організацій. Зокрема, відділ зі сталого розвитку ОOH (DSD) прагне забезпечити лідерство і стимулювати дії у просуванні та координації реалізації узгоджених на міжнародному рівні цілей розвитку, включаючи сімнадцять Цілей сталого розвитку (С3Г) [21]. Робота підрозділу полягає у виконанні основних функцій: підтримка міжурядових процесів ООН щодо сталого розвитку; аналіз та розробка політики; розвиток потенціалу державчленів; міжвідомча координація; залучення зацікавлених сторін, партнерство, спілкування та інформаційно-просвітницька діяльність; управління знаннями. Експерти Bertelsmann Stiftung та UN Sustainable Development Solutions Network (SDSN) щорічно розраховують Sustainable Development Goal Index по 149 країнах світу [18]. Даний індекс містить 77 індикаторів (економічних, соціальних, екологічних та інших показників). Значення індексу розраховується в межах від 1 до 100 балів та враховує ступінь досягнення певною країною 17 цілей сталого розвитку. До першої двадцятки за результатами 2018року увійшли скандинавські країни та країни Північної Європи (табл. 1). Проте слід зазначити, що навіть лідери даного рейтингу не отримали найвищого балу (Швеція - 85,6 зі 100 балів у 2016 році, 85,0 - у 2018 році), що свідчить про недосягнення 100\% виконання цілей сталого розвитку жодною країною. 
Таблиця 1 - Країни-лідери за SDG Index2016 - 2018pp.

\begin{tabular}{|l|l|l|}
\hline Kраїна & SDG Index -2016 & SDG Index - 2018 \\
\hline Sweden & 85,6 & 85,0 \\
\hline Denmark & 84,2 & 84,6 \\
\hline Finland & 84,0 & 83,0 \\
\hline Norway & 83,9 & 81,2 \\
\hline Czech Republic & 81,9 & 78,7 \\
\hline Germany & 81,7 & 82,3 \\
\hline Austria & 81,4 & 80,0 \\
\hline Switzerland & 81,2 & 80,1 \\
\hline Slovenia & 80,5 & 80,0 \\
\hline France & 80,3 & 81,2 \\
\hline Japan & 80,2 & 78,5 \\
\hline Belgium & 80,0 & 79,0 \\
\hline Netherlands & 79,9 & 79,5 \\
\hline Iceland & 79,3 & 79,7 \\
\hline Estonia & 78,6 & 78,3 \\
\hline United Kingdom & 78,3 & 78,7 \\
\hline Hungary & 78,0 & 75,0 \\
\hline Ireland & 77,9 & 77,5 \\
\hline New Zealand & 77,6 & 77,9 \\
\hline
\end{tabular}

Джерело: складено автором за даними [18]

Іншим індексом, за допомогою якого оцінюють сталий розвиток країн, $€$ Індекс Екологічної Ефективності (ЕРI) [14]. ЕРІ використовує ієрархічну структуру, яка групує індикатори за категоріями, визначає категорії у межах цілей політики та в загальному індексі. Розрахунок ЕРI базується на досягненні на двох цілей: охорона навколишнього середовища, яка вимірює загрозу здоров'ю людей, та життєздатність екосистеми, яка вимірює природні ресурси та екосистемні послуги. Зазначені цілі відображають домінуючу сферу державної політики, в рамках вирішуються екологічні проблеми. У багатьох урядах є департаменти або міністерства, що займаються питаннями охорони здоров'я та природних ресурсів, портфелі яких відповідають цілям політики СІП [22]. Кожного року переглядаються показники, які приймаються для розрахунку з врахуванням їх адекватності та відкритості даних. Лідери останніх років за ЕРI зазначені у табл. 2. 
Таблиця 2 - Країни-лідери за ЕРI 2014 - 2018pp.

\begin{tabular}{|c|c|c|c|c|c|}
\hline \multicolumn{2}{|c|}{2014} & \multicolumn{2}{|c|}{2016} & \multicolumn{2}{c|}{2018} \\
\hline Kpaїна & EPI & Kpaїна & EPI & Kpaїна & EPI \\
\hline Switzerland & 87,67 & Finland & 90,88 & Switzerland & 87,42 \\
\hline Luxembourg & 83,29 & Iceland & 90,51 & France & 83,95 \\
\hline Australia & 82,40 & Sweden & 90,43 & Denmark & 81,60 \\
\hline Singapore & 81,78 & Denmark & 89,21 & Malta & 80,90 \\
\hline Czech Republic & 81,47 & Slovenia & 88,98 & Sweden & 80,51 \\
\hline Germany & 80,47 & Spain & 88,91 & United Kingdom & 79,89 \\
\hline Spain & 79,79 & Portugal & 88,63 & Luxembourg & 79,12 \\
\hline Austria & 78,32 & Estonia & 88,59 & Austria & 78,97 \\
\hline Sweden & 78,09 & Malta & 88,48 & Ireland & 78,77 \\
\hline Norway & 78,04 & France & 88,20 & Finland & 78,64 \\
\hline Netherlands & 77,75 & New Zealand & 88,00 & Iceland & 78,57 \\
\hline United Kingdom & 77,35 & United Kingdom & 87,38 & Spain & 78,39 \\
\hline Denmark & 76,92 & Australia & 87,22 & Germany & 78,37 \\
\hline Iceland & 76,50 & Singapore & 87,04 & Norway & 77,49 \\
\hline Slovenia & 76,43 & Croatia & 86,98 & Belgium & 77,38 \\
\hline New Zealand & 76,41 & Switzerland & 86,93 & Italy & 76,96 \\
\hline Portugal & 75,80 & Norway & 86,90 & New Zealand & 75,96 \\
\hline Finland & 75,72 & Austria & 86,64 & Netherlands & 75,46 \\
\hline Ireland & 74,67 & Ireland & 86,60 & Israel & 75,01 \\
\hline Estonia & 74,66 & Luxembourg & 86,58 & Japan & 74,69 \\
\hline
\end{tabular}

Джерело: складено автором за даними [14]

Науковцями Світового центру даних 3 геоінформатики та сталого розвитку [23] розроблено власну методологію оцінювання рівня сталого розвитку країн у розрізі компонентів якості та безпеки життя. Під індексом сталого розвитку в даному контексті розуміють кількісну міру сталого розвитку, яка враховує безпеку та якість життя людей. Компонента якості життя - це інтегрована оцінка, яка враховує сумісно усі три виміри сталого розвитку (економічний, екологічний, соціальний). Баланс між економічним, екологічним та соціально-інституційним вимірами відображає ступінь гармонізації сталого розвитку. Компонента безпеки життя - це інтегрована оцінка, яка враховує сумарний вплив сукупності загроз на сталий розвиток регіонів, а індекс вразливості регіону до впливу сукупності загроз відображає ступінь наближення цього регіону одночасно до усіх загроз у просторі [23]. Двадцять країн-лідерів, визначених відповідно до доданої методики, наведені у табл. 3: 
Таблиця 3 - Країни-лідери за ISD

\begin{tabular}{|l|l|}
\hline Країна & SDGIndex \\
\hline Switzeeland & 2,92 \\
\hline Sweden & 2,92 \\
\hline Iceland & 2,91 \\
\hline Norway & 2,90 \\
\hline Australia & 2,89 \\
\hline Finland & 2,89 \\
\hline New Zealand & 2,88 \\
\hline Luxembourg & 2,85 \\
\hline Canada & 2,83 \\
\hline Denmark & 2,82 \\
\hline Germany & 2,80 \\
\hline Netherlands & 2,80 \\
\hline Austria & 2,79 \\
\hline United Kingdom & 2,75 \\
\hline United States & 2,75 \\
\hline Japan & 2,72 \\
\hline Belgium & 2,69 \\
\hline France & 2,69 \\
\hline Ireland & 2,63 \\
\hline Singapore & 2,59 \\
\hline
\end{tabular}

Джерело: складено автором за даними [19]

Аналіз різних методологічних підходів дозволяє дійти висновку, що високорозвинені країні мають як високі економічні показники, так і мають можливості спрямовувати частину витрат на виконання соціальних та екологічних вимог до сучасного суспільства 3 метою забезпечення сталого розвитку на майбутнє. На основі кореляційного аналізу між основними макроекономічними показниками за 2004 - 2016 рр. було виявлено наступні залежності (табл. 4). Для аналізу було обрано двадцять країн, які були лідерами за рейтингом ЕРІ-2016, оскільки цей рік найбільш представлено у відкритих базах даних.

Країни, які мають високий рівень доходів на душу населення, мають різний економічний уклад, про що свідчать значення $\mathrm{K}_{4}$ та $\mathrm{K}_{5}$. Проте деякі країни (Естонія, Сінгапур), які мають доволі щільний зв'язок між доданою вартістю як сільського господарства, так і промисловості з ВВП на душу населення. Така картина може свідчити про високий наявний потенціал національної економіки та віддачу вкладених ресурсів. Як свідчать дані табл. 4, серед країн, що приділяють більше інших увагу захисту навколишнього середовища, відсутня чітка пряма або зворотна залежність між орієнтованістю країни на промисловий або сільськогосподарський розвиток. Водночас, у всіх країнах простежується щільний прямий зв'язок між розвитком інформаційно-комунікаційних та індексом екологічної ефективності, що свідчить зменшення шкідливого впливу на навколишнє середовище з розвитком наукоємного виробництва та сфери послуг. 
Таблиця 4 - Результати кореляційного аналізу макроекономічних показників

\begin{tabular}{|l|c|c|r|r|r|r|r|r|r|}
\hline \multicolumn{1}{|c|}{ Країна } & $\begin{array}{c}\text { Рівень } \\
\text { доходу }\end{array}$ & \multicolumn{1}{c|}{$\mathrm{K}_{1}$} & \multicolumn{1}{c|}{$\mathrm{K}_{2}$} & \multicolumn{1}{c|}{$\mathrm{K}_{3}$} & \multicolumn{1}{c|}{$\mathrm{K}_{4}$} & $\mathrm{~K}_{5}$ & $\mathrm{~K}_{6}$ & \multicolumn{1}{c|}{$\mathrm{K}_{7}$} & $\mathrm{~K}_{8}$ \\
\hline Finland & високий & 0,698 & 0,129 & 0,852 & 0,264 & 0,462 & 0,038 & $-0,233$ & $-0,278$ \\
\hline Iceland & високий & 0,586 & $-0,220$ & 0,861 & 0,428 & 0,101 & 0,173 & 0,325 & 0,158 \\
\hline Sweden & високий & 0,745 & 0,573 & 0,917 & 0,226 & 0,418 & $-0,134$ & 0,777 & $-0,227$ \\
\hline Denmark & високий & 0,404 & 0,359 & 0,875 & 0,523 & 0,281 & $-0,450$ & 0,811 & $-0,501$ \\
\hline Slovenia & високий & 0,445 & 0,317 & 0,965 & 0,544 & 0,473 & 0,877 & $-0,147$ & 0,785 \\
\hline Spain & високий & 0,019 & $-0,279$ & 0,975 & $-0,392$ & $-0,591$ & 0,884 & 0,380 & 0,267 \\
\hline Portugal & високий & $-0,233$ & 0,003 & 0,964 & $-0,607$ & $-0,301$ & $-0,589$ & $-0,561$ & $-0,631$ \\
\hline Estonia & високий & 0,630 & 0,718 & 0,860 & 0,742 & 0,755 & 0,489 & $-0,390$ & 0,852 \\
\hline Malta & високий & $-0,197$ & 0,541 & 0,864 & $-0,111$ & 0,159 & $-0,696$ & $*$ & $-0,561$ \\
\hline France & високий & 0,372 & 0,388 & 0,931 & $-0,039$ & $-0,060$ & 0,753 & 0,781 & 0,770 \\
\hline New Zealand & високий & 0,879 & 0,670 & 0,935 & 0,509 & 0,903 & 0,301 & $*$ & 0,361 \\
\hline United Kingdom & високий & 0,420 & $-0,198$ & 0,925 & 0,101 & 0,363 & 0,082 & $-0,268$ & $-0,065$ \\
\hline Australia & високий & 0,578 & 0,717 & 0,880 & 0,765 & 0,634 & 0,682 & 0,560 & 0,647 \\
\hline Singapore & високий & 0,285 & 0,376 & 0,661 & 0,965 & 0,984 & 0,863 & $*$ & $-0,354$ \\
\hline Croatia & середній & 0,028 & 0,217 & 0,922 & 0,073 & 0,347 & 0,424 & 0,389 & 0,555 \\
\hline Switzerland & високий & 0,277 & 0,501 & 0,318 & 0,536 & 0,679 & 0,700 & $-0,944$ & 0,871 \\
\hline Norway & високий & 0,604 & 0,393 & 0,890 & $-0,150$ & $-0,553$ & $-0,382$ & $-0,753$ & 0,588 \\
\hline Austria & високий & 0,432 & 0,545 & 0,986 & 0,076 & 0,237 & 0,633 & 0,705 & 0,576 \\
\hline Ireland & високий & 0,285 & 0,062 & 0,895 & 0,222 & 0,862 & 0,181 & $-0,649$ & $-0,964$ \\
\hline Luxembourg & високий & 0,437 & 0,525 & 0,898 & 0,255 & 0,260 & 0,527 & 0,807 & 0,375 \\
\hline
\end{tabular}

Примітка: $\mathrm{K}_{1}$ - коефіцієнт кореляції між доданою вартістю сільського господарства та EPI; К $K_{2}$ - коефіцієнт кореляції між доданою вартістю промисловості та ЕPI; К 3 коефіцієнт кореляції між розвитком інформаційно-комунікаційних технологій та ЕPI; $\mathrm{K}_{4}-$ коефіцієнт кореляції між доданою вартістю сільського господарства та ВВП на душу населення; $\mathrm{K}_{5}$ - коефіцієнт кореляції між доданою вартістю промисловості та ВВП на душу населення; $\mathrm{K}_{6}$ - коефіцієнт кореляції між високотехнологічним експортом та ВВП на душу населення; $\mathrm{K}_{7}$ - коефіцієнт кореляції між GINI та ВBП на душу населення; К 8 коефіцієнт кореляції між витратами на дослідження та обсягом високо-технологічного експорту; * - відсутні дані для розрахунку.

Джерело: розраховано автором за даними [23]

Оскільки вкладення у наукові розробки, збільшення виробництва та експорту високотехнологічної продукції дозволяє отримати більшу додану вартість як на мікро-, так і на макрорівнях, то результати кореляційного аналізу ( $\mathrm{K}_{6}$ та $\left.\mathrm{K}_{8}\right)$ математично підтверджують підстави стрімкого економічного розвитку країн, які обрали для себе стратегію активного інноваційного розвитку (Сінгапур, Швейцарія, Іспанія, Словенія, Франція та інші). Відповідно до концепції сталого розвитку суспільні інвестиції мають бути спрямовані не лише у забезпечення економічного добробуту, а на розвиток соціальної та екологічної програми. Водночас, аналіз взаємозв’язку залежності рівня розшарованості населення та обсягом виробленого ВВП у країні не має однозначного трактування $\left(\mathrm{K}_{7}\right)$. Зокрема, кількісне значення коефіцієнта кореляції між індексом GINI та ВВП на душу населення має розмах від $-0,944$ до $+0,811$. 
Останнім часом відбувається активне впровадження IT-технологій у процеси виробництва та управління бізнес-процесами, що ознаменувалося новою хвилею промислової революції Індустрія 4.0. Термін «Індустрія 4.0» 3'явився у Німеччині у 2011 році, звернувши увагу на розробку стратегії перетворення виробничих підприємств країни у «розумні». За Німеччиною пішли інші країни, активно розвиваючи та впроваджуючи новітні технології. Роботизоване виробництво та «smart» підприємства стали визначальними об'єктами перетворень. Особливістю четвертої промислової революції $\epsilon$ автоматизація всіх процесів суспільного виробництва: від розробки ідеї до доставки готового продукту до споживача 3 врахуванням його вподобань. При чому виробник має можливість дистанційно здійснювати післяпродажний сервіс та оперативно приймати необхідні рішення, здійснюючи обробку великих даних. Німецькі початківці визначили основні принципи впровадження Індустрії 4.0 підприємствами: сумісність спроможність машин, пристроїв, сенсорів та людей взаємодіяти один з одним через інтернет речей (ІоТ); прозорість - у віртуальному світі створюється цифрова копія реальних об'єктів, систем, що відтворює все, що відбувається з іiі фізичним прототипом. Це дозволяє отримати повну інформацію про всі процеси, які відбуваються 3 обладнанням, «розумними» продуктами, виробництвом в цілому тощо, що у свою чергу потребує матеріального забезпечення процесу збору відповідних даних з первинних джерел, де вони генеруються; технічна підтримка - комп'ютерні системи мають допомагати людям приймати рішення завдяки збору, аналізу та візуалізації вищезазначеної інформації. Така допомога передбачає або повну заміну людей машинами для виконання небезпечних або ж рутинних операцій; децентралізація управлінських рішень, в тому числі передача деяких 3 них кіберфізичним системам. Автоматизація має бути настільки максимальною, наскільки це можливо, кінцевим результатом передбачається максимальне заміщення людини машиною. Працівникам залишається роль контролерів, які мають підключатися в екстрених та нестандартних ситуаціях.

Зазначені перетворення спонукають зміни у бізнес-моделях. Ощадливе виробництво поступово перетворюватиметься у персоналізований випуск продукції з дотриманням принципу економії, оскільки роботизоване виробництво $є$ більш ефективним, як з точки зору енергоресурсів, так і інших ресурсів [11].

Проте перехід до повної автоматизації виробництва та заміщення людини технікою поступово призводитиме до потенційного зростання безробіття, що викликатиме зростання соціального напруження у суспільстві. Зокрема, за оцінками фахівців компанії Deloitte, 65 \% дітей, які зараз навчаються у початковій школі, будуть працювати на робочих місцях, які не існують сьогодні, а до 2030 року кожен п'ятий робітник не буде мати навіть базової освіти. Два мільярди робочих місць будуть замінені автоматизацією до 2030 року[13]. Водночас, як зазначають практики, на сьогодні відчувається потреба у висококваліфікованих кадрах, які впроваджуватимуть 
ідеї Індустрії 4.0. Задля забезпечення сталого розвитку суспільства необхідним є збалансований розвиток, що поєднує економічні, соціальні та екологічні цілі.

Як показали результати проведеного дослідження, за багатьма макроекономічними показниками Україна поступається високорозвиненим країнам. Водночас наявність потенційних ресурсів, якими володіє наша країна, не використовується ефективно через використання застарілих технологій та зношених основних засобів на більшості промислових підприємств. У даному контексті одним зі шляхів подолання такого розриву вважаємо впровадження та системне застосування IT-технологій у менеджменті підприємства. На думку експертів, для внутрішнього ринку України Індустрія 4.0 має стати каталізатором зростання промисловості, а також оборонно-промислового комплексу. Величезний виклик для Індустрії 4.0 на внутрішньому ринку - це залучення до дигіталізації української промисловості та енергетики IT-сектору, а також науки. Наразі обидві категорії сильно випадають 3 цих процесів [12]. У грудні 2018 року групою експертів від АППАУ та руху 4.0 було розроблено Проект національної стратегії Індустрія 4.0. На даний час він перебуває на розгляді в КМУ та доступний для експертного обговорення. Головним завданням для України $є$ визначення свої ніші у глобальному ринку. За оцінками експертів країна наразі і в найближчі 5 років немає умов для будь-якого позиціонування серед лідерів - провідних 20-30 постіндустріальних держав світу. Натомість, Україна може бути як мінімум регіональним лідером у сфері складних та наукоємних інженерних послуг, таких як:- програмування у сфері промислових хайтек (створення нових програмних продуктів, включно на нових технологіях 4.0);проектування

(електричне, механічне, електронне, технологічне, будівельне тощо);- промислова автоматизація та комплексний інжиніринг (включно 3 введенням в експлуатацію промислових об'єктів);- $\quad$ розробка та виробництво складних, малосерійних або унікальних виробів [12].

При цьому ключовими моментами стратегії Індустрія 4.0 [12] для України є:

1. Інституціоналізація розвитку промислових хайтек-сегментів на рівні держави, що передбачає визнання цільових секторів промислових хайтек як ключових для розвитку економіки України. Для забезпечення виконання даного завдання держава в особі уряду країни здійснити реформи задля стимулювання в Україні промислового виробництва, у тому числі за сегментами середньо- та високотехнологічної продукції; забезпечити захист прав власності, верховенство права, доступ до фінансових ресурсів та інституційна спроможність уряду; створити умови для прискореного розвитку промислових хайтек-сегментів, надаючи їм відповідний пріоритет та стимули.

2. Створення інноваційної екосистеми промислових хайтек, що потребує вирішення наступних завдань: повний незалежний аудит існуючих 
елементів екосистеми; налагодження трансферу технологій від українських наукових установ, наукових парків, міжнародних центрів та корпорацій до кінцевих замовників; залучення інвестицій та фондів до прискорення інноваційного розвитку тощо.

3. Прискорення кластеризації у сфері 4.0 як на регіональному, так i національному рівнях, що дозволить вирішити низку завдань в межах кластеру, а також стимулюватиме зростання експорту.

4. Повномасштабна дигіталізація ключових секторів промисловості, енергетики та інфраструктури, що потребує створення регуляторних стимулів, дорожніх карт цифрової трансформації в цільових галузях, а також перенесення кращих бізнес-практик 3 IT-сектору у дані сектори разом 3 підвищенням цифрових знань та навичок керівників і персоналу.

5. Максимальна інтеграція інновацій 4.0 в стратегії оборонного комплексу та безпеки країни шляхом запуску спеціальних державних програм для переходу оборонних заводів на технології 4.0 та підвищення їх інноваційності, інтеграція в державні програми з упередження техногенних ризиків тощо.

6. Запуск експортних програм для промислових хайтек-секторів шляхом створення спеціальної торгової місії 3 експорту продуктів та сервісних послуг у сфері 4.0, а також спеціальних програм щодо покращання експортного потенціалу промислових хайтек-сегментів.

7. Інтернаціоналізація та інтеграція у світовий простір 4.0, що передбачає інтеграцію в такі європейські програми, як Horizon 2020, I4MS / DIH, Factory of the Future, a також окремі програми європейських держав, тощо.

Вважаємо, що реалізація заходів, передбачених стратегією Індустрія 4.0 дозволить підвищити ефективність національного виробництва, а відповідно, і конкурентоспроможність національної економіки на світовому ринку. При цьому необхідно враховувати базові положення концепції сталого розвитку - поєднання економічної, екологічної та соціальної складової для забезпечення збалансованості.

Висновки. В результаті проведеного дослідження встановлено, що питаннями оцінювання рівня сталого розвитку країн світу та його складових займається декілька міжнародних організацій, які не зважаючи на застосування різних методологічних засадах надають ідентичні результати, а саме: лідерами за рівнем сталого розвитку є скандинавські країни та країни Північної Європи, які мають високий рівень життя. Виявлено закономірність - навіть країни-лідери не мають 100\% виконання цілей сталого розвитку. Науковою новизною роботи $\epsilon$ виявлена на основі кореляційного аналізу залежність: рівень сталого розвитку, в першу чергу, визначає інноваційна активність країни, а не їі галузева спрямованість.

Практичне значення отриманих результатів полягає в систематизації заходів, необхідних для забезпечення сталого розвитку України, на засадах реалізації Індустрії 4.0, а саме: індустріалізація розвитку промислових 
високотехнологічних сегментів економіки, створення інноваційної промислової екосистеми, прискорення кластеризації та дигіталізації 3 урахуванням сутності процесів Індустрії 4.0, тощо.

Перспективним напрямом подальших досліджень є розвиток наукових положень щодо оцінювання ефективності науково-технічних заходів, спрямованих на забезпечення сталого розвитку суспільства, в рамках Індустрії 4.0.

\section{Література:}

1. Аналіз соціально-економічних процесів розвитку суспільства, заснованого на знаннях: наук. кер. проекту М. З. Згуровський. К.: КПІ ім. Ігоря Сікорського. 2017. 26 с.

2. Аналіз сталого розвитку - глобальний і регіональний контексти:Міжнар. рада 3 науки (ICSU) та ін.; наук. кер. проекту M. З. Згуровський. Ч. 1. Глобальний аналіз якості та безпеки життя. К. : КПІ ім. Ігоря Сікорського. 2017. 208 с.

3. Аналіз сталого розвитку - глобальний і регіональний контексти: Міжнар. рада з науки (ICSU) та ін.; наук. кер. М. 3. Згуровський. Ч. 2. Україна в індикаторах сталого розвитку. К.: НТУУ «КПІ». 2010. 220 с.

4. Васюткіна Н. В. Управління сталим розвитком підприємств: теоретикометодологічний аспект. К. : Ліра-К. 2014. 334 с.

5. Ватченко О.Б.,Ільченко В.М.Виникнення та аналіз поняття «сталий розвиток» // Вісник Дніпропетровської державної фінансової академії: Зб. наук. пр. «Економічні науки». Дніпропетровськ. 2011. № 1.С. 64-68.

6. Герасимчук 3. В. Регіональна політика сталого розвитку: теорія, методологія, прак-тика : монографія. Луцьк: Надстир'я. 2008. 528 с.

7. Данилишин Б. М., ЧернюкЛ. Г., ФащевськийМ. І. Просторова організація продуктивних сил України: мезо - та мікроре-гіональний рівень. Вінниця: Книга-Вега. 2007. 572 c.

8. Дейлі Г. Поза зростанням. Економічна теорія сталого розвитку. К. : Інтелсфера. 2002. $312 \mathrm{c.}$

9. Основи стійкого розвитку: навчальний посібник; за заг. ред. д. е.н., проф. Л. Г.Мельника. Суми: ВТД «Університетська книга». 2005. 654 с.

10. Пакулін С. Л.,Пакуліна А. А. Управління сталим розвитком сучасного підприємства $\begin{array}{lll}/ / \text { Траектория } \quad \text { науки. №3(8). } & \text { URL: }\end{array}$ http://pathofscience.org/index.php/ps/article/view/50.

11. Рагимова С. Цифровая индустрия 4.0 URL:http://www.forbes.ru/brandvoicephotogallery/sap/345705-desyat-faktorov-menyayushchih-vsyo

12. Юрчак О. Українська стратегія Індустрії 4.0 - 7 напрямів розвитку. URL: https://industry4-0-ukraine.com.ua/2019/01/02/ukrainska-strategiya-industrii-4-0-7napriankiv-rozvutku/

13. Deloitte Global Chief Executive Officerand Chairman of the Board.URL:https://www2.deloitte.com/content/campaigns/global/global-report/index.html

14. Environmental Performance Index. URL: https://epi.envirocenter.yale.edu/

15. Meadows D.H., Meadows D.L. andRanders J. BeyondtheLimits: GlobalCollapseor a SustainableFuture. Earthscan: London. 1992.

16. Prescott-Allen R. TheWellbeingofNations: A Country-by-Country Index of Quality of Life and the Environment. London: UNEP/IslandPress, 2001.

17. SDGCOMPASS: Посібник для досягнення Цілей Сталого Розвитку в сфері бізнесу // Глобальна Ініціатива зі Звітності, Глобальний договір $\mathrm{OOH}$, Всесвітня рада підприємців зі сталого розвитку. URL: https://sdgcompass.org/wpcontent/uploads/2016/09/SDG_Compass_Guide_Ukranian.pdf

18. SDG Inex\& DashboardsReport. URL: http://www.sdgindex.org/ 
19. Sustainable development analysis: global and regional contexts / International Council for Science etc.; scientific adviser M. Zgurovsky. Part 1. Global analysis of quality and security of life (2013), K. : NTUU “KPI". 2014.168 p.

20. Sustainable Development Goals: Ukraine (National baseline report). Ministry of economic development and trade of Ukraine. 2017.4168 p. URL:https://drive.google.com/drive/u/0/folders/0B9O3ySgVVRL5MTJHMFBqQUQtNkk

21. Sustainable development knowledge platform. URL: ttps://sustainabledevelopment.un.org/

22. The 2018 Environmental Performance Index. Methodology. URL: https://epi.envirocenter.yale.edu/2018-epi-report/methodology

23. The official web-site of World Data Center for Geoinformatics and Sustainable Development. URL:http://wdc.org.ua/

УДК 338.27

JEL classification: $03, Q 4, Q 5$

Шевчук О.А. канд. економ. наук, доцент

Борданова Л. С. канд. економ. наук

Наухацька Т.А.

Національний технічний університет Украӥни «Київський політехнічний інститут імені Ігоря Сікорського»

\section{ОПТИМІЗАЦІЯ ЕНЕРГОЕФЕКТИВНОСТІ ЕКОНОМІКИ ЗА ДОПОМОГОЮ ТЕХНОЛОГІЧНОЇ КОНЦЕПЦIÏ SМАRT GRID}

\section{THE ECONOMY ENERGY EFFICIENCY OPTIMIZATION USING SMART GRID TECHNOLOGICAL CONCEPT}

В статті розглядається питання сучасного стану електроенергетики та можливі шляхи подальшого розвитку. Зокрема, особлива увага зосереджена на реалізачіі концепиіï Smart grid. Аналізуючи передумови та причини розвитку «інтелектуальних» мереж доведено, щзо впровадження концепиіï Smart grid є природним етапом еволюиіi електроенергетичної системи. «Розумні» мережі - це закономірний етап розвитку соціально-економічних відносин, реалізований в технологічну концепцію. $У$ ходi оиінювання переваг, недоліків та досвіду країн зроблено висновок, щзо Smart grid - ие не стільки технологія, скільки інструмент розвитку нетрадиційної, децентралізованої (розподіленої) енергетики. Така система - надзвичайно ефективний інструмент геоекономічного та геополітичного управління, вона не тільки підтримує єдність регіонів $i$ економічних комплексів краӥни, а й діє як інструмент, що забезпечує начіональний суверенітет і можливість протидіяти зовнішньому тиску в енергетичній сфері в його організаційних, технологічних тощзо. формах, в тому числі в умовах надзвичайних ситуачій військового, природного $i$ m.n. характеру [17]. Синтезуючи виявлено, щзо запровадження технологій Smart grid повинно відбуватися в умовах тісної взаємодії спеціалістів в області енергетики і інформаційних технологій з широким використанням імітаційних моделей на різних рівнях планування і розробки. Головними иілями повинні стати безпека та безперебійне постачання енергією, автоматичний контроль за 